Annals of Plant and Soil Research 22(4): 410-414 (2020)

https://doi.org/10.47815/apsr.2020.10013

\title{
Performance of spider plant (Chlorophytum comosum) in modular vertical green walls under various media and nutrients
}

\author{
D. DHANASEKARAN, K. RAMYA AND C.T.SATHAPPAN
}

Department of Horticulture, Faculty of Agriculture, Annamalai University, Annamalai Nagar (Tamil Nadu)

Received: August, 2020; Revised accepted: October, 2020

\begin{abstract}
An investigation was carried out to study the performance of various media and nutrients for spider plant (Chlorophytum comosum) in modular vertical walls under vertical green walls in the Department of Horticulture, Annamalai University, Annamalai Nagar (Tamil Nadu) during 2018 to 2020. The experiment comprised of four media viz., coco peat, greenosil, perlite and vermiculite and their combinations and two nutrients viz., foliar nutrition (Grosure NPK 19:19:19 and @1\% twice (30 and 90 days after planting)) and fertilizer stick (Greenstix sticks were inserted to the modular containers @ one per container at 30 and 90 days after planting). Results revealed that, among the media, plants grown under vermiculite showed better performance in exhibiting maximum values for plant height $(24.9 \mathrm{~cm})$, number of leaves (21.6), leaf length (23.8 $\mathrm{cm})$, leaf width (2.43), leaf area $\left(30.9 \mathrm{~cm}^{2}\right)$, shoot weight $\left(15.1 \mathrm{~g} \mathrm{plant}^{-1}\right)$, root weight $\left(3.4 \mathrm{~g} \mathrm{plant}^{-1}\right)$, biomass $\left(18.4 \mathrm{~g} \mathrm{plant}^{-1}\right)$, size index $(24.7 \mathrm{~cm})$, and visual quality (9.08). However, among the nutrients, plants inserted with fertilizer stick recorded highest values for plant height $(20.9 \mathrm{~cm})$, number of leaves (18.8), leaf length (20.9 $\mathrm{cm})$, leaf width (2.21), leaf area $\left(30.2 \mathrm{~cm}^{2}\right)$, shoot weight (14.8 g plant $\left.{ }^{-1}\right)$, root weight (3.24 g plant $\left.{ }^{-1}\right)$, biomass $\left(18.1 \mathrm{~g} \mathrm{plant}^{-1}\right)$, size index $(22.5 \mathrm{~cm})$, and visual quality (8.49). compared with foliar nutrition. The interaction between media and nutrients was significant and plants grown under vermiculite and containers inserted with fertilizer stick showed superior performance in exerting maximum values for all the characters than other treatment combinations.
\end{abstract}

Keywords: Vertical green walls-media, nutrients, fertilizer sticks, spider plant

\section{INTRODUCTION}

In the last few years the attention towards the environment seems to have become one of the primary objectives to follow. The ecological theories developed from the seventies onwards, have contributed to the diffusion of a better awareness as far as our actions on a global level are concerned. The integration of vegetation can play an important role, especially in dense urban areas with lack of green zones, becoming the scene of important environmental issues relative to pollution in the atmosphere with consequences on the physical wellbeing and comfort of the local inhabitants. In general terms the main benefits connected to a green building envelope regard environmental practices, economics, and social aspects, as the greenhouse gases output reduction, climate change adaptation, air quality and indoor and outdoor comfort conditions improvement, urban wildlife (biodiversity). Living wall systems (LWS), which are also known as green walls and vertical gardens, are constructed from modular panels which contain soil or other artificial growing mediums such as foam, perlite and rock wool.
Vertical gardens, which allow growth of various species of plants in the complicated city life, balance urban ecology and enhance the quality of urban life.

Containerised plant production presents two fundamental challenges for healthy root growth. First, unlike a normal soil profile, a container environment provides a very shallow layer of growing medium which becomes quickly saturated during irrigation. Essentially, an effective growing medium must have a physical structure that is capable of sustaining a favourable balance between air and water storage both during and between irrigation events in order to prevent root asphyxia and drought stress. The inability of soil to provide this balance at such small volumes is a key driver in the development of soilless growing media. Indeed, these media have been a pivotal innovation, allowing growers to carefully control water, air and nutrient supply to the plant roots whilst excluding soil borne pathogens (Raviv et al., 2002). However; there are some general considerations that apply to all soilless growing media. As well as an appropriate physical structure, a growing medium must provide a 
suitable biological and chemical environment in which plant roots can effectively access nutrients. Foliar spray enables plants to absorb the applied nutrients from the solution through their leaf surface and thus, may result in the economic use of fertilizer (Manasa et al., 2015). Slow release fertilizers (SRFs) involve the release of the nutrient in a slower manner than common fertilizers. However, the rate, pattern and duration of release are not well controlled. Fertilizer sticks, also referred to as fertilizer spikes or stakes, are compressed fertilizers that are manufactured in stick form. Fertilizer sticks produce a constant supply of nutrients into the soil. As you water the plant, the stick dissolves, releasing the nutrients into the soil, where they are taken up by the roots. Hence, an experiment was formulated to study the effect of various media and nutrients on Spider plant (Chlorophytum comosum) under vertical green wall system.

\section{MATERIALS AND METHODS}

The present investigation was carried out in the Department of Horticulture, Annamalai University, Annamalai Nagar (TamilNadu) during the year 2018 to 2020.The experiment comprised of seven media viz., M1-coco peat, M2-greenosil, M3-perlite,M4-vermiculite, M5cocpeat + Greenosil, m6-cocopeat + perlite and M7-Cocopeat + vermiculite and three nutrients viz., N1-Control, N2-foliar nutrition (Grosure NPK 19:19:19 and @ 1\% twice (30 and 90 days after planting)) and N3-fertilizer stick (Greenstix sticks were inserted to the modular containers @ one per container at 30 and 90 days after planting). Modular containers of size $12 \mathrm{~cm} \mathrm{x11} \mathrm{cm} \mathrm{x} 8 \mathrm{~cm}$ were fabricated in a netted vertical panel equipped with drip irrigation system. Growing media were filled up leaving one inch form the top of the modular containers. In addition, 50 grams of vermicompost was added to all the modular containers to enhance the initial growth. Spider plant of uniform size were planted in the modular containers and grown in the fabricated vertical green wall.The experiment was conducted in factorial completely randomized design. Three plants were selected at random from each treatment and tagged for the purpose of recording various biometric observations in all the three ornamental species. The plant growth characters like plant height, number of leaves per plant, leaf length, leaf width, leaf area, shoot weight, root weight, biomass, size index, and visual quality were observed at 150 days after planting The statistical analysis of data was done by adopting the standard statistical procedure given by Panse and Sukhatme (1967). The critical difference was worked out for 5 per cent level of significance.

\section{RESULTS AND DISCUSSION}

\section{Effect of media}

Among the media, the tallest plant (24.9 $\mathrm{cm})$, maximum number of leaves (21.6), highest leaf length $(23.8 \mathrm{~cm})$ and leaf width $(2.43 \mathrm{~cm})$, highest leaf area $\left(30.9 \mathrm{~cm}^{2}\right)$, maximum shoot weight (15.1 $\left.\mathrm{g} \mathrm{plant}^{-1}\right)$, highest root weight (3.40 $\mathrm{g}$ plant $\left.{ }^{-1}\right)$, maximum biomass (18.4 $\mathrm{g} \mathrm{plant}^{-1}$ ), maximum size index $(24.7 \mathrm{~cm})$ and maximum visual quality value (9.08) were observed in vermiculite which were significantly higher than perlite. However, minimum plant height (15.9 $\mathrm{cm})$, number of leaves (14.2), lowest leaf length $(16.3 \mathrm{~cm})$, minimum leaf width $(1.83 \mathrm{~cm})$, lowest leaf area $\left(24.1 \mathrm{~cm}^{2}\right)$, minimum shoot weight $(11.5$ $\mathrm{g}$ plant $\left.^{-1}\right)$, lowest root weight (1.86 $\left.\mathrm{g} \mathrm{plant}^{-1}\right)$, lowest biomass (13.6 g plant $\left.{ }^{-1}\right)$, minimum size index $(19.2 \mathrm{~cm})$ and minimum visual quality (6.89) were observed in greenosil. Plants grown under vermiculite showed maximum values for vegetative characters ultimately resulted in enhancement visual quality and ornamental importance. Vermiculite is the most common physical growth substrate which is known for its high water holding capacity, inert chemical nature, and moderate level of aeration, absence of substrate for microbial growth and effective cation exchange capacity which may be the reason for enhancing the morphology of all the three foliage ornamentals. Further, it can hold 3 4 times its weight of water and positive-charged nutrients such as $\mathrm{K}, \mathrm{Mg}$ and $\mathrm{Ca}$. The results of the present study are in consonance with the study made by Indrasumunar and Gresshoff, (2013). The primitive effect of vermiculite are in accordance of the findings of Zhang et al. (2012) in petunia and El-Naggar (2005) in gladiolus.

\section{Effect of nutrients}

Among the nutrient treatments, maximum plant height $(20.9 \mathrm{~cm})$, maximum number of 
Table1: Influence of media and nutrients on growth and performance of spider Plant

\begin{tabular}{|c|c|c|c|c|c|c|c|c|c|c|}
\hline Treatment & $\begin{array}{l}\text { Plant height } \\
\text { (cm) }\end{array}$ & $\begin{array}{c}\text { Number } \\
\text { of } \\
\text { leaves }\end{array}$ & $\begin{array}{l}\text { Leaf } \\
\text { length } \\
(\mathrm{cm})\end{array}$ & $\begin{array}{l}\text { Leaf } \\
\text { width } \\
(\mathrm{cm})\end{array}$ & $\begin{array}{l}\text { Leaf } \\
\text { area } \\
\left(\mathrm{cm}^{2}\right)\end{array}$ & $\begin{array}{c}\text { Shoot } \\
\text { weight } \\
\left.\text { (g plant }^{-1}\right)\end{array}$ & $\begin{array}{c}\text { Root } \\
\text { weight } \\
\text { (g plant }^{-1} \text { ) }\end{array}$ & $\begin{array}{l}\text { Biomass } \\
\text { (gplant }^{-1} \text { ) }\end{array}$ & $\begin{array}{c}\text { Size } \\
\text { index } \\
\text { (cm) }\end{array}$ & $\begin{array}{l}\text { Visual } \\
\text { qua- } \\
\text { lity }\end{array}$ \\
\hline \multicolumn{11}{|l|}{ Interaction } \\
\hline $\mathrm{M}_{1} \mathrm{~N}_{0}$ & 16.5 & 13.7 & 15.2 & 1.72 & 23.3 & 9.62 & 2.01 & 11.1 & 19.2 & 7.13 \\
\hline $\mathrm{M}_{2} \mathrm{~N}_{0}$ & 15.2 & 11.3 & 15.1 & 1.61 & 21.3 & 9.07 & 1.01 & 10.9 & 18.4 & 6.54 \\
\hline $\mathrm{M}_{3} \mathrm{~N}_{0}$ & 21.9 & 15.8 & 20.9 & 2.03 & 25.0 & 9.88 & 2.31 & 12.2 & 20.9 & 8.07 \\
\hline $\mathrm{M}_{4} \mathrm{~N}_{0}$ & 23.8 & 20.1 & 22.4 & 2.17 & 26.3 & 10.3 & 2.55 & 12.9 & 23.0 & 8.09 \\
\hline $\mathrm{M}_{5} \mathrm{~N}_{0}$ & 16.3 & 12.8 & 15.7 & 1.96 & 22.8 & 9.76 & 1.19 & 11.0 & 18.8 & 7.01 \\
\hline $\mathrm{M}_{6} \mathrm{~N}_{0}$ & 17.2 & 13.1 & 14.9 & 1.81 & 22.2 & 9.98 & 1.58 & 11.6 & 19.1 & 7.99 \\
\hline $\mathrm{M}_{7} \mathrm{~N}_{0}$ & 17.3 & 13.4 & 16.1 & 1.8 & 22.0 & 9.43 & 1.54 & 11.0 & 19.9 & 8.12 \\
\hline $\mathrm{M}_{1} \mathrm{~N}_{1}$ & 20.7 & 15.2 & 18.9 & 1.97 & 26.3 & 14.0 & 2.32 & 15.5 & 20.4 & 8.01 \\
\hline $\mathrm{M}_{2} \mathrm{~N}_{1}$ & 16.2 & 14.1 & 15.9 & 1.92 & 25.3 & 12.1 & 1.91 & 14.0 & 19.3 & 6.99 \\
\hline $\mathrm{M}_{3} \mathrm{~N}_{1}$ & 22.0 & 18.2 & 22.2 & 2.3 & 29.8 & 14.4 & 2.98 & 17.4 & 23.8 & 9.12 \\
\hline $\mathrm{M}_{4} \mathrm{~N}_{1}$ & 24.7 & 21.6 & 23.2 & 2.43 & 31.8 & 16.1 & 3.02 & 19.1 & 25.0 & 9.21 \\
\hline $\mathrm{M}_{5} \mathrm{~N}_{1}$ & 16.7 & 13.7 & 16.0 & 2.12 & 28.8 & 13.3 & 2.08 & 15.4 & 19.7 & 8.12 \\
\hline $\mathrm{M}_{6} \mathrm{~N}_{1}$ & 18.1 & 16.2 & 17.0 & 2.02 & 28.3 & 13.1 & 2.16 & 15.3 & 20.1 & 8.1 \\
\hline $\mathrm{M}_{7} \mathrm{~N}_{1}$ & 17.9 & 17.2 & 17.1 & 2.01 & 27.0 & 12.8 & 2.24 & 15.0 & 22.0 & 8.19 \\
\hline$M_{1} N_{2}$ & 22.9 & 18.2 & 21.1 & 1.98 & 29.0 & 14.6 & 2.94 & 17.5 & 23.0 & 8.32 \\
\hline $\mathrm{M}_{2} \mathrm{~N}_{2}$ & 16.3 & 17.0 & 18.0 & 1.98 & 25.8 & 13.3 & 2.65 & 16.0 & 19.8 & 7.16 \\
\hline $\mathrm{M}_{3} \mathrm{~N}_{2}$ & 25.2 & 22.2 & 24.0 & 2.52 & 32.8 & 16.6 & 3.76 & 19.9 & 25.4 & 9.3 \\
\hline $\mathrm{M}_{4} \mathrm{~N}_{2}$ & 26.2 & 23.1 & 25.9 & 2.71 & 34.8 & 18.6 & 4.64 & 23.3 & 26.0 & 9.93 \\
\hline $\mathrm{M}_{5} \mathrm{~N}_{2}$ & 17.2 & 17.5 & 17.9 & 2.14 & 29.8 & 13.6 & 2.86 & 16.5 & 19.8 & 8.16 \\
\hline $\mathrm{M}_{6} \mathrm{~N}_{2}$ & 20.0 & 17.1 & 21.9 & 2.02 & 30.0 & 13.9 & 2.99 & 16.9 & 21.9 & 8.26 \\
\hline $\mathrm{M}_{7} \mathrm{~N}_{2}$ & 18.9 & 17.0 & 18.3 & 2.12 & 29.3 & 14.1 & 2.87 & 16.9 & 22.1 & 8.36 \\
\hline CD $(0.05 \%)$ & 0.84 & 0.91 & 1.31 & 0.14 & 1.86 & 0.97 & 0.17 & 1.13 & 0.62 & 0.46 \\
\hline \multicolumn{11}{|l|}{ Media } \\
\hline$M_{1}$ & 20.1 & 15.7 & 18.4 & 1.89 & 26.2 & 12.7 & 2.42 & 14.7 & 20.9 & 7.82 \\
\hline$M_{2}$ & 15.8 & 14.2 & 16.3 & 1.83 & 24.1 & 11.5 & 1.86 & 13.6 & 19.2 & 6.89 \\
\hline$M_{3}$ & 23.1 & 18.7 & 22.4 & 2.28 & 29.2 & 13.6 & 3.01 & 16.5 & 23.3 & 8.84 \\
\hline $\mathrm{M}_{4}$ & 24.8 & 21.6 & 23.8 & 2.43 & 30.9 & 15.1 & 3.4 & 18.4 & 24.7 & 9.08 \\
\hline $\mathrm{M}_{5}$ & 16.7 & 14.7 & 16.6 & 2.07 & 27.1 & 12.2 & 2.04 & 14.3 & 19.4 & 7.76 \\
\hline$M_{6}$ & 18.4 & 15.5 & 18.0 & 1.95 & 26.8 & 12.3 & 2.24 & 14.6 & 20.3 & 8.12 \\
\hline$M_{7}$ & 18.1 & 15.9 & 17.2 & 1.97 & 26.1 & 12.1 & 2.21 & 14.3 & 21.3 & 8.22 \\
\hline CD (0.05 \%) & 0.48 & 0.58 & 0.75 & 0.08 & 1.12 & 0.56 & 0.10 & 0.65 & 0.32 & 0.24 \\
\hline \multicolumn{11}{|l|}{ Nutrients } \\
\hline $\mathrm{N}_{0}$ & 18.2 & 14.3 & 17.2 & 1.87 & 23.2 & 9.72 & 1.74 & 11.5 & 19.9 & 7.56 \\
\hline $\mathrm{N}_{1}$ & 19.5 & 16.6 & 18.6 & 2.11 & 28.1 & 14.1 & 2.39 & 16.0 & 21.5 & 8.24 \\
\hline $\mathrm{N}_{2}$ & 20.9 & 18.8 & 20.9 & 2.21 & 30.2 & 14.8 & 3.24 & 18.1 & 22.5 & 8.49 \\
\hline CD $(0.05 \%)$ & 0.37 & 0.34 & 0.49 & 0.05 & 0.72 & 0.37 & 0.06 & 0.42 & 0.28 & 0.21 \\
\hline
\end{tabular}

M1-Cocopeat, M2-Greenosil; M3-Perlite; M4-Vermiculite, M5- Coco peat + Greenosil (1:1);M6- Coco peat + Perlite (1:1);M7Coco peat + Vermiculite (1:1);N1- Foliar nutrition (19:19:19) 1\% spray; N2- Fertilizer stick @ one stick per pot

leaves (18.8), maximum leaf length $(20.8 \mathrm{~cm})$, maximum leaf width $(2.21 \mathrm{~cm})$, maximum leaf area $\left(30.1 \mathrm{~cm}^{2}\right)$, maximum shoot weight $(14.8 \mathrm{~g}$ plant $\left.^{-1}\right)$, maximum root weight $\left(3.24 \mathrm{~g} \mathrm{plant}^{-1}\right)$, maximum biomass (18.1 $\left.\mathrm{g}_{\text {plant }}{ }^{-1}\right)$, maximum size $(22.5 \mathrm{~cm})$ and highest visual quality (8.49) were observed in fertilizer stick which was significantly higher than foliar nutrition. However, minimum plant height $(18.1 \mathrm{~cm})$, number of leaves (14.3), minimum leaf length $(17.1 \mathrm{~cm})$, minimum leaf width $(1.87 \mathrm{~cm})$, minimum leaf area $\left(23.2 \mathrm{~cm}^{2}\right)$, minimum shoot weight $(9.72 \mathrm{~g}$ plant $\left.^{-1}\right)$, root weight $\left(1.74 \mathrm{~g} \mathrm{plant}^{-1}\right)$, minimum biomass (11.5 g plant ${ }^{-1}$ ), minimal size index $(19.8 \mathrm{~cm})$ and lowest visual quality (7.56) were observed in control. The superiority of the treatment with fertilizer stick on various vegetative characters may be due to plant growth conditions, such as reduction of stress and specific toxicity resulting from excessive 
nutrient supply in the root zones (Fig.1). The fertilizer sticks produce a constant supply of up by the roots. The results of Kumar et al. (2018) evinced that the Enhanced Efficiency Fertilizers (EEF) are more efficient from fertilizer sticks compared to conventional fertilizer formulations with respect to nutrient uptake by the crops and persistent behaviour in the substrate soil for a longer period of time.Similar findings were reported by Geicu-Cristea et al. (2016) in Petunia and Dainthus sp, Jagadeeswaran et al. (2007) in Turmeric, Dehgan et al. (2004) in Zamia floridana.

\section{Interaction effect of media and nutrients}

Interaction of media and nutrients showed significant difference for plant height in Arrow head plant. However, the maximum plant height $(26.1 \mathrm{~cm})$, maximum number of leaves (23.0), maximum leaf length $(25.9 \mathrm{~cm})$, maximum leaf width $(2.71 \mathrm{~cm})$, highest leaf area $\left(34.7 \mathrm{~cm}^{2}\right)$, highest shoot weight $\left(18.6 \mathrm{~g} \mathrm{plant}^{-1}\right)$, highest root weight $\left(4.64 \mathrm{~g} \mathrm{plant}^{-1}\right)$, maximum biomass (23.2 $\mathrm{g} \mathrm{plant}^{-1}$ ), maximum size index $(26.0 \mathrm{~cm})$ and maximum visual quality (9.93) were observed in $\mathrm{M}_{4} \mathrm{~N}_{2}$ (Vermiculite + Fertilizer stick). However, minimum plant height (15.1 $\mathrm{cm}$ ), number of leaves (11.3), minimum leaf length $(15.0 \mathrm{~cm})$, minimum leaf width $(1.61 \mathrm{~cm})$, lowest leaf area $\left(21.2 \mathrm{~cm}^{2}\right)$, lowest shoot weight $\left(9.07 \mathrm{~g} \mathrm{plant}^{-1}\right)$, lowest root weight (1.01 g plant $\left.{ }^{1}\right)$, lowest biomass $\left(10.8 \mathrm{~g} \mathrm{plant}^{-1}\right)$, minimum size

\section{REFERENCES}

Chen. Y., Bracy, R. P., Owings, A. D. and Quebedeaux, J. P. (2011) Controlledrelease fertilizer type and rate affect landscape establishment of seven herbaceous perennials. Horticultural Technology 21(3): 336-342.

Dehgan, B., Almira, F.C., Dudeck, A.E. and Schutzman, B.(2004) Effects of varying shade and fertilizer on the growth of Zamia floridana A. DC. The Botanical Review 70 (1): 79-85.

El-Naggar, A.H. (2005) Effect of foliar nutrition on growth, flowering, corms and cormels production of gladiolus plants. Alexandria Science Exchange 26 (1): 19 nutrients into the media which dissolve slowly and release the nutrients, where they are taken index $(18.4 \mathrm{~cm})$ and minimum visual quality (6.54) were observed in $\mathrm{M}_{2} \mathrm{~N}_{0}$ (Greenosil + Control). Media and nutrients are the two major factors influencing the containerized ornamental plants. Plants grown under suitable media and supply of essential quantities of nutrients at right time determines the compact growth of plants. The synergetic effect of media and nutrients results in better plant growth and development. In the present investigation, the influence of media and nutrients are found to be significant in expressing commendable results. The enhanced effect of fertilizer stick may be due to increase in the availability of nutrients due to the controlled release of nutrients into a "fixing" medium during the fixation processes in the media (vermiculite) as well as supplying nutrients in the forms preferred by plants; in that way the synergistic effect between nutrients and media. Further, the controlled release fertilizer improves nutrient use efficiency (NUE) and reduces losses of surplus nutrients. . The results obtained from Chen et al. (2011), Jagadeeswaran et al. (2007), Sempeho et al.(2014), Geicu-Cristea et al.(2016) are in agreement with the present study.

Hence, from the present experiment, it could be concluded that spider plant performed better under the media vermiculite and applied with fertilizer stick Greeenstix @ 1 per container at 60 days interval.

Geicu-Cristea, M., Popa, M. E., Miteluţ, A.C., Danaila-Guidea, S.M. and Neata, G. (2016) Research on agriculture applications of some newly developed biobased products. Agriculture and Agricultural Science Procedia 10: 485493.

Indrasumunar, A. and Gresshoff, P. M. (2013) Vermiculite's strong buffer capacity renders it unsuitable for studies of acidity on soybean (Glycine max L.) nodulation and growth. BMC Research notes 6 (1): 465.

Jagadeeswaran, R., Murugappan, V., Govindaswamy, M. and Kumar, P.S.D. 
(2007) Influence of slow release fertilizers on soil nutrient availability under turmeric (Curcuma longa L.). Asian Journal of Agricultural Research 1 (3): 105-111.

Kumar, K.M., Hanumanthappa, M., Marimuthu,S. and Meenambigai, C. (2018) A review on enhancing the fertilizers use efficiency to minimize environmental impacts. International Journal of Chemical Sciences 6 (3): 2167-2174.

Manasa, V., Hebsur,N.S., Malligawad,L.H., Kumar,L.S. and Ramakrishna, B.(2015) Effect of water soluble fertilizers on uptake of major and micro nutrients by groundnut and post harvest nutrient status in a vertisol of northern transition zone of Karnataka. The Ecoscan 9 (1-2): 01-05.
Panse, V.G., and Sukhatme, P.V. (1967) Statistical methods for agricultural workers ICAR Publication, New Delhi 259.

Raviv, M., Wallach, R., Silber, A. and Bar-Tal, A. (2002). Substrates and their analysis. Embryo Publications, Athens.

Sempeho, S.I., Kim, H.T., Mubofu, E. and Hilonga, A. (2014) Meticulous overview on the controlled release fertilizers. Advances in Chemistry 2(1):23-26.

Zhang, W., Li, X., Chen, F. and Lu, J. (2012) Accumulation and distribution characteristics for nitrogen, phosphorus and potassium in different cultivars of Petunia hybrida Vlim. Scientia Horticulturae 141: 83-90. 